Wiarygodność

dwuwymiarowej metody

prognozowania wymiarów

dróg oddechowych

u pacjentów po operacjach

ortognatycznych

\section{Reliability of two \\ dimensional airway prediction method for orthognathic surgery patients}

\author{
Kevser Kurt Demirsoy ${ }^{1}$ ADE (ORCID ID: 0000-0001-7271-4377) \\ Gokhan Coban 2 BC (ORCID ID: 0000-0001-6066-005X) \\ Gokmen Kurt ${ }^{3}$ AEF (ORCID ID: 0000-0003-0632-2433)
}

\begin{abstract}
Wkład autorów: $\mathbf{A}$ Plan badań $\mathbf{B}$ Zbieranie danych $\mathbf{C}$ Analiza statystyczna $\mathbf{D}$ Interpretacja danych E Redagowanie pracy $\mathbf{F}$ Wyszukiwanie piśmiennictwa
\end{abstract}

Authors' Contribution: A Study design $\mathbf{B}$ Data Collection $\mathbf{C}$ Statistical Analysis $\mathbf{D}$ Data Interpretation E Manuscript Preparation $\mathbf{F}$ Literature Search

${ }^{1}$ Katedra Ortodoncji, Uniwersytet Nevsehir Haci Bektas Veli, Wydział Stomatologii, Turcja Orthodontics, Nevsehir Haci Bektas Veli University, Faculty of Dentistry, Turkey

${ }^{2}$ Katedra Ortodoncji, Uniwersytet Erciyes, Wydział Stomatologii, Turcja Orthodontics, Erciyes University, Faculty of Dentistry, Turkey Orthodontics

${ }^{3}$ Katedra Ortodoncji, Uniwersytet Fundacji Bezmialem, Wydział Stomatologii, Turcja Bezmialem Foundation University, Faculty of Dentistry, Turkey

\section{Streszczenie}

Drogi oddechowe są obszarem anatomicznym, na który mogą wpływać zabiegi z zakresu chirurgii ortognatycznej. Dokładne prognozowanie zmian w drogach oddechowych przed operacją ortognatyczną jest ważne w odniesieniu do planowania leczenia chirurgicznego. Cel. Celem niniejszego badania była ocena wiarygodności dwuwymiarowej metody

\begin{abstract}
The pharyngeal airway is an anatomical region that can be affected by orthognathic surgery. Accurate prediction of pharyngeal airway changes before orthognathic surgery is important for surgical treatment planning. Aim. The aim of this study was to evaluate the reliability of two dimensional pharyngeal airway prediction method on orthognathic
\end{abstract}

Adres do korespondencji/Correspondence address:

Kevser Kurt Demirsoy

Orthodontics, Nevsehir Haci Bektas Veli University, Faculty of Dentistry, Turkey

e-mail: k_ldemirsoy@hotmail.com

\title{
@(1)@(2)
}

Copyright: (C) 2005 Polish Orthodontic Society. This is an Open Access journal, all articles are distributed under the terms of the Creative Commons Attribution-NonCommercial-ShareAlike 4.0 International (CC BY-NC-SA 4.0) License (http://creativecommons.org/licenses/by-nc-sa/4.0/), allowing third parties to copy and redistribute the material in any medium or format and to remix, transform, and build upon the material, provided the original work is properly cited and states its license. 
prognozowania wymiarów dróg oddechowych u pacjentów po operacjach ortognatycznych z różnymi wzorcami kostnymi. Materiał i metody. Badaniem objęto 25 pacjentów po operacjach ortognatycznych (18 osób z klasą szkieletową III i 7 osób z klasą szkieletową II). Prognozowanie wymiarów dróg oddechowych wykonano, stosując oprogramowanie Dolphin Imaging (w wersji 11.0), a następnie wyniki porównano z cefalogramami bocznymi wykonanymi co najmniej 6 miesięcy po operacji ortognatycznej. Do prognozowania wymiarów dróg oddechowych gardła zastosowano analizę FAB (ang. face, airway, bite - twarz, drogi oddechowe, zgryz) Arnetta/Gunsona. Ocenę między grupami przeprowadzono, stosując test $t$ dla par, a do oceny między grupami użyto niezależnego testu t. Wyniki. W grupie klasy II dla długości podniebienia miękkiego (Spl), wymiarów dróg oddechowych jamy ustnej i gardła (Opa) oraz nosogardzieli (Npa) uzyskano prognozowane wartości podobne do wyników cefalometrii pooperacyjnej $(\mathrm{P}>0,05)$, aczkolwiek stwierdzono istotne różnice w odniesieniu do wymiarów dróg oddechowych gardła dolnego (Hpa) i gardła głębokiego (Dpa) $(\mathrm{P}<0,05)$. W grupie klasy III dla regionów Npa, Opa i Hpa wartości prognozowane różniły się w sposób statystycznie istotny od wyników rzeczywistych $(\mathrm{P}<0,05)$. Wniosek. Stwierdzono, że prognozowane wartości wymiarów dróg oddechowych gardła dokonane na podstawie analizy FAB w oprogramowaniu 2D Dolphin Imaging są bardziej zgodne z wynikami pooperacyjnymi u pacjentów z klasą szkieletową II po operacjach ortognatycznych w porównaniu z pacjentami z klasą szkieletową III po operacjach ortognatycznych. W procesie planowania operacji ortognatycznych należy uwzględnić wzorzec kostny pacjenta oraz zmiany w drogach oddechowych. (Demirsoy KK, Coban G, Kurt G. Wiarygodność dwuwymiarowej metody prognozowania wymiarów dróg oddechowych u pacjentów po operacjach ortognatycznych. Forum Ortod 2021; 17 (4): 263-8).

Nadesłano: 25.10.2021

Przyjęto do druku: 13.12.2021

https://doi.org/10.5114/for.2021.112338

Słowa kluczowe: chirurgia ortognatyczna, prognozowanie wymiarów dróg oddechowych, analiza FAB Arnetta/Gunsona

\section{Introduction}

Orthognathic surgical procedures inevitably affect soft tissues and anatomical spaces by changing skeletal tissues position. The most affected areas are the oropharyngeal region, which contains many vital functions such as breathing and swallowing (1). The pharyngeal region has a complex structure. The pharyngeal region has a complex structure. It mainly consists of tongue, soft palate, hyoid bone, epiglottis and a group of muscles. After surgical procedures, the surgery patients have different skeletal patterns. Material and methods. The study included 25 orthognathic surgery patients (18 skeletal Class III and seven skeletal Class II). Airway predictions were made with Dolphin Imaging software (Version 11.0) and compared with lateral cephalograms taken at least six months after orthognathic surgery. Arnett/Gunson FAB (face, airway, bite) analysis was used for pharyngeal airway prediction. Intra-group evaluation was made with Paired-t test, and independent-t test was used for inter-group evaluation. Results. In Class II group Soft palate length (Spl), Oropharyngeal airway (Opa) and Nasopharyngeal airway (Npa) measurements were predicted similar with postoperative cephalometric results $(\mathrm{P}>0.05)$, although significant differences were found in Hypopharyngeal airway (Hpa) and Deeppharyngeal airway (Dpa) $(\mathrm{P}<0.05)$. In Class III group Npa, Opa and Hpa regions were predicted statistically different from the actual results $(\mathrm{P}<0.05)$. Conclusion. The pharyngeal airway space prediction made by FAB analysis of the 2D Dolphin Imaging software was found to be more consistent with the postoperative results in skeletal Class II orthognathic surgery patients compared to skeletal Class III orthognathic surgery patients. In orthognathic surgery planning, the skeletal pattern of the patients and airway changes should be considered. (Demirsoy KK, Coban G, Kurt G. Reliability of two dimensional airway prediction method for orthognathic surgery patients. Orthod Forum 2021; 17 (4): 263-8).

Received: 25.10 .2021

Accepted: 13.12 .2021

https://doi.org/10.5114/for.2021.112338

Key words: orthognathic surgery, airway prediction, Arnett/ Gunson FAB analysis

morphology of these structures is affected, which causes changes in respiratory efficiency $(2,3)$.

After osteotomies performed during orthognathic surgery, there may be a reflexive change in the pharyngeal muscular mechanism and supra and infra-hyoid muscles, and therefore adaptive changes in soft and hard tissues $(3,4)$.

Soft-hard tissue and airway changes are important considerations for an ideal planning in orthognathic surgery patients (5). Preoperative prediction methods that predict 
Reliability of two dimensional airway prediction method for orthognathic surgery patients

soft tissue and airway changes similar to the final results are preferred by both orthodontists and surgeons. While patients are mostly interested in soft tissue changes, changes in important vital functions such as pharyngeal airway space (PAS) are critical issues that physicians should pay attention due to PAS dimensions affect the patient's quality of life (6). Today, many 2D and 3D prediction methods are used for soft-hard tissue and airway prediction. While 2D and 3D methods can be used in post-surgical soft tissue and airway predictions, 2D cephalometric films are part of common diagnosis and treatment planning equipment that used by orthodontists and surgeons in terms of both radiation dose and accessibility (7). Dolphin Imaging (Dolphin Imaging \& Management Solutions $®$, Chatsworth, CA, ABD) (DI), is one of the frequently used software types that offers 2D and 3D soft-hard tissue and airway prediction options (6-9). This software uses a landmark-based transformation algorithm validated using lateral cephalograms and 2D photographs (6). While previous studies in the literature reported that this software is confident in PAS measurements and offers few errors, it is suggested that more studies are needed to prove the accuracy and reproducibility of airway prediction methods in general $(6,9,10)$. Therefore, the aim of this study was to evaluate the reliability of PAS prediction made by Arnett/Gunson FAB (face, airway, bite) analysis in 2D DI software compared with postoperative PAS in skeletal class II and class III orthognathic surgery patients.

\section{Material and methods}

This retrospective study reviewed data from 25 patients ( 7 skeletal Class II patients and 18 skeletal Class III patients) who had undergone mandibular advancement surgery for Class II patients and, maxillary advancement plus mandibular setback surgery for Class III patients. All patients met following criteria;

a. No history of facial trauma and congenital anomaly,

b. 'CVMI (cervical vertebrae maturation indicators) 6' completion stage for cervical spine maturation assessment,

c. No previous history of orthodontic treatment or orthognathic surgery,

d. Class II patients must be treated with mandibular advancement surgery by bilateral sagittal split osteotomy (BSSO), and Class III patients must be treated with Le Fort 1 maxillary advancement surgery (no maxillary down-fracture or impaction osteotomies) and mandibular setback surgery with BSSO, without any additional surgical procedures (e.g., genioplasty, malar augmentation, rhinoplasty),

e. All cephalograms must be taken by one operator at the same machine, taken just before the surgery and at least six months after orthognathic surgery in the Natural Head Position (NHP). f. No change in upper incisor positions just before and after surgery. The patients consisted of people who treated at the Department of Orthodontics and Oral and Maxillofacial Surgery at XXX University Faculty of Dentistry. First group included 7 skeletal Class II patients ( 4 women and 3 men; ANB angle greater than $4^{\circ}$; mean age: $25.4 \pm 6.80$ ) and second group included 18 skeletal Class III patients ( 10 women and 8 men, ANB angle less than $0^{\circ}$; mean age: $25.1 \pm 7.40$ ).

The same orthodontic treatment protocol was utilized in all cases included for this study, and orthognathic surgery was achieved for all individuals by the same surgery team. The post-surgical orthodontic treatment was continued on average four weeks after the surgery. The lateral cephalograms were taken at two time periods. T0; immediate preoperative (2-4 days before surgery for surgical planning) and T1; post-treatment period (after orthodontic debonding process, at least six months after the orthognathic surgery; $10.5 \pm 3.77$ months on average). Cephalograms were analyzed in the Dolphin Imaging (Version 11.0) computer program. PAS prediction was made by Arnett/Gunson FAB analysis of preoperative cephalometric films and these values were compared with postoperative PAS measurements. PAS prediction analyses and postoperative cephalometric analyses were done by the same orthodontist.

The PAS was evaluated with measuring pharyngeal width at different levels using Arnett/Gunson FAB analysis $(11,12)$ and measurements used for this study are shown in Figure. The measurements were;

1. Soft palate length (Spl): was evaluated with the distance between the posterior nasal spine (PNS) and the tip of the soft palate.

2. Nasopharyngeal airway (Npa): The width ( $\mathrm{mm})$ of the Npa was determined by drawing a line perpendicular to the TVL (true vertical line) passed through the point $\mathrm{A}$, and then the distance between the landmarks of the same line with the posterior and the anterior walls of the pharynx was measured.

3. Oropharyngeal airway (Opa): The width of the Opa (mm) was measured by a line perpendicular to the TVL that passed through the tip of the upper central incisor (U1T).

4. Hypopharyngeal airway (Hpa): The width ( $\mathrm{mm}$ ) of the Hpa was determined at B point level, and the distance between the landmarks that were put on the front and the back walls of the airway was measured.

5. Deeppharyngeal airway (Dpa): The width ( $\mathrm{mm}$ ) of the Dpa was measured at the landmark Pog level with similar way.

To determine method error, half of all material (on 25 of a total of 50 radiographs taken at periods $\mathrm{T} 0$ and T1) was evaluated again three weeks after the completion of all measurements by the same orthodontist. Correlation coefficients "rs" were calculated by comparing the first and second measurements. ICC determined in all measurements and it was 
K. K. Demirsoy et al.

found the range between 0.845-0.967. Paired t-test was used for statistical evaluations within groups, and independent t-test was used for statistical evaluations between groups and $\mathrm{P}<0.05$ significance level was adopted.

\section{Results}

This study sample consisted of 25 patients and two groups (Class II: 7 patients, Class III: 18 patients). The reliability of 2D Dolphin Imaging (Version 11.0) Arnett/Gunson FAB (face, airway, bite) analysis' airway predictions on skeletal Class II and Class III orthognathic surgery patients was evaluated. Intra-group evaluation results of PSA measurements for Class II and Class III cases are given in Table 1, and intergroup evaluation results are given in Table 2 .

In the intragroup evaluation, there was no statistically significant difference between the predictive and final values of the soft palate length (Spl), nasopharyngeal airway width (Npa) and oropharyngeal airway width (Opa) variables in the Class II group ( $>0.05)$, while hypopharyngeal (Hpa) and deeppharyngeal (Dpa) airway widths were significantly different $(\mathrm{P}<0.05)$. In the Class III group, while the prediction of Spl and Dpa variables was consistent with the final values, a statistically significant difference was found between the prediction and final values for the Npa, Opa and Hpa variables $(\mathrm{P}<0.05)$. A statistically significant difference was found between the predictive and final values of the Npa, Hpa and Dpa variables in the evaluation between the groups $(\mathrm{P}<0.05)$.

\section{Discussion}

The aim of this study is to assess 2D airway prediction method's reliability of PAS prediction in skeletal class II and class III orthognathic surgery patients. The pharyngeal region is a complex structure and the pharynx has many vital functions such as breathing, speaking and swallowing. Studies show that various therapeutic applications such as orthopedic treatment and orthognathic surgery cause changes in the pharynx diameter, upper airway size and volume (13-15).

In this study, PAS prediction was made on 2D lateral cephalograms. Lateral cephalography, computed tomography (CT), and magnetic resonance imaging (MRI) are used to view the PAS $(15,16)$. Morphologically correct imaging of airway volumes and dimensions is important, especially in individuals with obstructive sleep apnea (OSA). Although studies in the literature report that CT and MRI images are more effective than two-dimensional images in airway evaluation (5), conventional lateral cephalograms are the easiest to interpret, the most cost-effective, relatively low radiation dose compared to CBCTs, and the most accessible method (17). Therefore, lateral cephalography remains the radiographic standard for airway assessment $(15,18)$.
Table 1. Intra-group evaluation results of PAS measurements for Class II and Class III treatment groups

\begin{tabular}{ccccc}
\hline $\begin{array}{c}\text { Treatment } \\
\text { Groups }\end{array}$ & PAS Measurements & $\boldsymbol{t}$ & $\boldsymbol{d} \boldsymbol{f}$ & $\boldsymbol{P}$ \\
\hline \multirow{3}{*}{ Class II } & Spl_Pr \& Spl_Act & 0.846 & 7 & 0.430 \\
& Npa_Pr \& Npa_Act & -1.135 & 7 & 0.300 \\
& Opa_Pr \&Opa_Act & 0.582 & 7 & 0.582 \\
& Hpa_Pr\&Hpa_Act & 6.362 & 7 & 0.001 \\
& Dpa_Pr\&Dpa_Act & 2.637 & 7 & 0.039 \\
\hline \multirow{3}{*}{ Class III } & Spl_Pr\&Spl_Act & -0.886 & 18 & 0.388 \\
& Npa_Pr \& Npa_Act & 3.724 & 18 & 0.002 \\
& Opa_Pr \& Opa_Act & 4.226 & 18 & 0.001 \\
& Hpa_Pr \& Hpa_Act & -3.825 & 18 & 0.001 \\
& Dpa_Pr \& Dpa_Act & -1.512 & 18 & 0.149 \\
\hline
\end{tabular}

Pr: Predicted results, Act: Actual results.

Table 2. Intergroup evaluation results of PAS measurements for Class II and Class III treatment groups

\begin{tabular}{cccc}
\hline PAS Measurements & $\boldsymbol{t}$ & $\boldsymbol{d} \boldsymbol{f}$ & $\boldsymbol{P}$ \\
\hline Spl & 1.313 & 25 & 0.202 \\
$\mathrm{Npa}$ & -2.953 & 25 & 0.007 \\
$\mathrm{Opa}$ & -1.601 & 25 & 0.123 \\
$\mathrm{Hpa}$ & 6.054 & 25 & 0.000 \\
$\mathrm{Dpa}$ & 2.735 & 25 & 0.012 \\
\hline
\end{tabular}

In this study Hpa and Dpa airway widths were predicted significantly different from actual results in Class II orthognathic surgery patients and also a statistically significant difference was found between the prediction and final values for the Npa, Opa and Hpa variables in Class III orthognathic surgery patients. While Hpa width was the area predicted incorrectly in both groups, Spl was the only measurement accurately predicted in both groups. It has been reported that maxillary advancement affects the soft palate muscles (15). Previous studies have consistently reported that people with OSA tend to be obese and have an excessively increased soft palate length, a very large tongue, micrognathia, and marked narrowing of the upper airway $(16,19)$. For this reason, it is important to accurately predict the $\mathrm{Spl}$ in the evaluation of the PAS. It has been stated that in orthognathic surgical procedures with mandibular setback, there is backward movement in the soft tissues in the oral region (uvula, tongue, epiglottis and soft palate), and this may result in a significant narrowing of the PAS especially in the Hpa (20). It has also been reported that this narrowing is observed in lateral cephalograms so it is important to accurately predict the Hpa in the evaluation of the PAS in Class III orhognathic surgery patients. In this study erroneous 


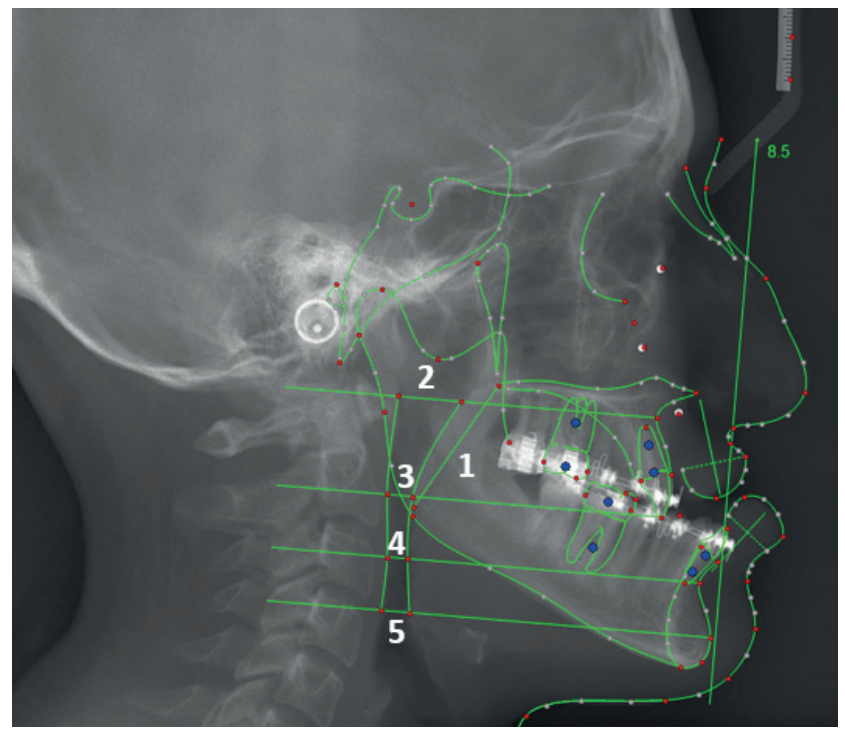

Figure 1. PAS measurements used in this study. 1: Soft palate length (Spl), 2: Nasopharyngeal airway (Npa); 3: Oropharyngeal airway (Opa), 4: Hypopharyngeal airway (Hpa), 5: Deeppharyngeal airway (Dpa).

predictions were made in also different PAS regions in Class II and Class III groups. The reason for this may be related to the difference in the movement directions in the maxilla and mandible during the surgical procedures.

In orthognathic surgery patients, prediction procedures can be performed for soft, hard tissues or airway. The compatibility of the prediction methods with the actual results is important in many respects such as the success of the treatment, the correct information of the patients, the transfer of the patient to the surgical environment with the most ideal amount of skeletal movement, and the positive effect on vital functions in the postoperative period. For this purpose, the ideal prediction method has been investigated in many studies $(6,7,9,18,21,22)$. The maxillofacial area is a kinetic region that contains many anatomical structures such as muscles, ligaments, and TMJ. Since these anatomical structures can show individual and racial differences, each prediction method should be made in line with certain algorithms, but taking into account individual differences. $3 \mathrm{D}$ predictions have many advantages over 2D predictions, especially in patients with asymmetry. Airway, soft or hard tissues are three-dimensional structures and predictions made in two planes may not always reflect the exact results. On the other hand, 2D programs have advantages due to reasons such as cost, accessibility, no tomography need, predictions can be performed with conventional cephalograms that contain much lower dose radiation than tomography. In this study, Dolphin Imaging was preferred as the 2D prediction method. There are some reasons why we prefer this method, which is widely used by orthodontists and maxillofacial surgeons, these are; it can predict changes in the sagittal and vertical planes, the procedure time is short, different types of surgery can be selected in different malocclusions, and it gives the feature of choosing the result based on some morphological criteria $(6,23)$. The error rate of this software, which was preferred in similar studies in which PAS measurements were made, was found to be higher in our study $(6,10,24)$.

There are some limitations of our study. First is the small number of samples, especially in the class II treatment group. It is thought that more precise data can be obtained with study groups with a large number of cases and also divided according to the amount of maxillomandibular movement, gender and surgery types. Although lateral cephalograms were taken at least 6 months after surgery to minimize the effect of edema on soft tissues and PAS in the postoperative period, they were taken at different times in each patient. Since studies evaluating the stability of the airway show that PAS values can change in the short and long term (25), conducting studies with cephalograms taken from each patient at the same time periods in both the short and long term will reduce the risk of bias of the study.

\section{Conclusions}

1. The pharyngeal airway space prediction made by FAB analysis of the 2D Dolphin Imaging software was found to be more consistent with the postoperative results in skeletal Class II orthognathic surgery patients compared to skeletal Class III orthognathic surgery patients.

2. In Class II group Soft palate length, Oropharyngeal airway and Nasopharyngeal airway measurements were predicted correctly, although Hypopharyngeal airway and Deeppharyngeal airway measurements were statistically different from the actual results.

3. In Class III group while Soft palate length and Deeppharyngeal airway measurements predicted similar with the actual results, statistically significant differences were calculated between predicted and final values of Nasopharyngeal airway, Oropharyngeal airway and Hypopharyngeal airway measurements. 


\section{Piśmiennictwo / References}

1. Wenzel A, Williams S, Ritzau M. Relationships of changes in craniofacial morphology, head posture and nasopharyngeal airway size following mandibular osteotomy. Am J Orthod Dentofacial Orthop 1989; 96: 138-43.

2. Enacar A, Aksoy AÜ, Şençift Y, Haydar B, Aras K. Changes inhypopharyngeal airway space and in tongue and hyoid bone positions following the surgical correction of mandibular prognathism. Int J Adult Orthod Orthognath Surg 1994; 9: 285-90.

3. Athanasiou AE, Toutoutzakis N, Mavreas D, Ritzaus M, Wenzel A. Alterations of hyoid bone position and pharyngeal depth and their relationship after surgical correction of mandibular prognathism. Am J Orthod Dentofacial Orthop 1991; 100: 259-65.

4. Wickwire NA, White RP, Proffit WR. The effect of mandibular osteotomy on tongue position. J Oral Surg 1972; 30: 184-90.

5. Faur CI, Roman RA, Bran S, Dinu C, Coclici A, Rotaru H, Hedesiu M. The Changes in Upper Airway Volume after Orthognathic Surgery Evaluated by Individual Segmentation on CBCT Images. Maedica 2019; 14: 213-9.

6. Yamashita AL, Iwaki LCV, Pinto GNS, Gerke BA, Chicarelli M, Iwaki Filho L. Accuracy of two-dimensional pharyngeal airway space prediction for bimaxillary orthognathic surgery. Oral Maxillofac Surg 2018; 22: 197-202.

7. Kolokitha OE, Topouzelis N. Cephalometric methods of prediction in orthognathic surgery. J Maxillofac Oral Surg 2011; 10: 236-45.

8. Kanavakis G, Häner ST, Matthey F, Gkantidis N. Voxel-based superimposition of serial craniofacial cone-beam computed tomographies for facial soft tissue assessment: Reproducibility and segmentation effects. Am J Orthod Dentofacial Orthop 2021; 159: 343-51.

9. Stokbro K, Aagaard E, Torkov P, Bell RB, Thygesen T. Virtual planning in orthognathic surgery. Int J Oral Maxillofac Surg 2014; 43: 957-65.

10. Alves M Jr, Baratieri C, Mattos CT, Brunetto D, Fontes Rda C, Santos JR, Ruellas AC. Is the airway volume being correctly analyzed? Am J Orthod Dentofacial Orthop 2012; 141: 657-61.

11. De Souza Carvalho ACG, Magro Filho O, Garcia Jr IR, Araujo PM, Nogueira RLM. Cephalometric and three-dimensional assessment of superior posterior airway space after maxillomandibular advancement. Int J Oral Maxillofac Surg 2012; 41: 1102-11.

12. Lopatienė K, Dabkutė A, Juškevičiūtè V. Vertical and sagittal morphology of the facial skeleton and the pharyngeal airway. Stomatol 2016; 18: 21-5.

13. Guimarães TM, Bariani RC, Iafigliola SG, et al. Cone beam computed tomography in assessment on pharynx effects of orthopedic-surgical treatment - a review of the literature. Sleep Sci 2019; 12: 106-9.

14. Cabral M, de Queiroz Ribeiro LR, Cardeal CM, Bittencourt MA, Crusoé-Rebello IM, Souza-Machado A. Evaluation of the oropharynx in Class I and II skeletal patterns by CBCT. Oral Maxillofac Surg 2017; 21: 27-31.

15. Aoki J, Shinozuka K, Yamagata K, Nakamura R, Sato T, Ohtani S, Ogisawa S, Yanagawa K, Tonogi M. Cephalometric analysis of the pharyngeal airway space after maxillary advancement surgery. J Oral Sci 2019; 27; 61: 529-33.
16. Lowe AA, Santamaria JD, Fleetham JA, Price C. Facial morphology and obstructive sleep apnea. Am J Orthod Dentofacial Orthop 1986; 90: 484-91.

17. Feng X, Li G, Qu Z, Liu L, Näsström K, Shi XQ. Comparative analysis of upper airway volume with lateral cephalograms and conebeam computed tomography. Am J Orthod Dentofacial Orthop 2015; 147: 197-204

18. Resnick CM, Inverso G, Wrzosek M, Padwa BL, Kaban LB, Peacock ZS. Is there a difference in cost between standard and virtual surgical planning for orthognathic surgery? J Oral Maxillofac Surg 2016; 74: 1827-33.

19. Lu M, Wang Z, Zhan X, Wei Y. Obstructive sleep apnea increases the risk of cardiovascular damage: a systematic review and meta-analysis of imaging studies. Syst Rev 2021; 30: 212.

20. Tseng YC, Hsiao SY, Cheng JH, Hsu KJ, Chen CM. Postoperative Skeletal Stability and Pharyngeal Airway: Counterclockwise versus Clockwise Rotation during Mandibular Setback Surgery. Biomed Res Int 2020; 30: 3283080.

21. Rodrigues E, Dhupar V, Akkara F. Understanding Predictability Error in Orthognathic Surgery. J Maxillofac Oral Surg 2019; 18: $474-8$.

22. Kim D, Ho DC, Mai H, Zhang X, Shen SGF, Shen S, Yuan P, Liu S, Zhang G, Zhou X, Gateno J, Liebschner MAK, Xia JJ. A clinically validated prediction method for facial soft-tissue changes following double-jaw surgery. Med Phys 2017; 44: 4252-61.

23. Kusnoto B. Two-dimensional cephalometry and computerized orthognathic surgical treatment planning. Clin Plast Surg 2007; 34: 417-26.

24. El H, Palomo JM. Measuring the airway in 3 dimensions: a reliability and accuracy study. Am J Orthod Dentofacial Orthop 2010; 137: 50e1-9.

25. Bin LR, Filho LI, Yamashita AL, de Souza Pinto GN, Mendes RA, Ramos AL, Dos Santos Previdelli IT, Iwaki LCV. How does bimaxillary orthognathic surgery change dimensions of maxillary sinuses and pharyngeal airway space? Angle Orthod 2020; 1: 715-22. 